\title{
短距離走に関する研究：コーチングに役立つ科学的根拠を求めて
}

伊藤章

\section{Scientific researches of sprint running: In search of scientific bases for coaching}

\begin{abstract}
Akira Ito
Abstract

As sprint running is such a basic movement for humans, it has been frequently used in research. Modern research on sprint running started in the early 1920s, and the neurological and muscular functions associated with sprint running and instinctive movements were the first to be investigated (Mero, 1992). Many studies have been conducted on improving the ability of humans to run sprint races, but as one problem has been solved, others have been raised. As a result, many issues remain to be addressed. These can be broadly categorized as: (1) mechanical efficiency in sprint running, (2) joint torque and power in sprint running, (3) muscular activity in sprint running, (4) the relationship between muscular activity and sprint running movements, (5) $100 \mathrm{~m}$ race patterns based on time analyses, and (6) the relationship between sprint running movements and speed.

The results of studies on areas 1-3 are important for improving sprint running ability. Basically, understanding the physiological functions involved in sprinting helps to clarify the associated technical and physical factors. The results of studies on areas 4-6 provide useful information for coaches and athletes. As the level of competition is very high, effective utilization of scientific data can be the key to the success of an athlete.

The present review concludes that the relationship between mechanical efficiency and sprint running cannot yet be clarified because there are no standardized methods for estimating mechanical work, and it is difficult to estimate anaerobic energy consumption during sprint running. In view of the fact that the degree of reutilization of elastic energy clearly influences mechanical efficiency, elastic energy makes less of a contribution to sprint running than it does to sub-maximal running.

Muscular activity is predominantly assessed using electromyography, but to ascertain the effects of muscular activity on sprint running, it is necessary to determine changes in the length of muscle-tendon complexes and joint torque. Baba et al. (2000) solved many of these problems and the organized complex factors involved in sprint running.

In recent years, many studies have been conducted to ascertain the relationships between

大阪体育大学:

干 590-0496 大阪府泉南郡熊取町朝代台 1-1

連絡先 侏藤 章

Osaka University of Health and Sport Sciences

1-1 Asashirodai, Kumatori-chou, Sennan-gun, Osaka 590-0496

Corresponding author aito@ouhs.ac.jp
\end{abstract}


sprint running movement and speed based on movement analyses of numerous athletes during competitions. These studies have identified characteristic movements in good sprinters and their significance. It appears that almost no correlation exists between sprint running speed and leg movement during the recovery phase, although a significant correlation between leg movement during the foot contact phase and sprint running speed has been identified. This type of information is extremely useful for coaches and sprinters.

\section{Key words : leg movement, joint torque, muscular activity, mechanical efficiency}

(Japan J. Phys. Educ. Hlth. Sport Sci. 48: 355-367, July, 2003)

キーワード: 下肢動作，関節トルク，筋活動，機
械的効率

\section{はじめに}

2 歳前後に走の基本的な動作パターンが形成さ れ，5歳では短距離競走ができるようになる（宮 丸，2001）。このように短距離走は人にとって最 も基本的な運動の一つであり，最も早くから行わ れる自然で単純な運動である，そのため，人の運 動能力を競うための代表的な方法として古代より 短距離競走が実施され，それぞれの時代の短距離 走チャンピオンは人類究極の記録の具現者として 尊敬されてきた。しかし，いつの時代も記録は伸 びつづけ, 現在も走路や用具の改善も含め, 人類 究極の $100 \mathrm{~m}$ 記録への挑戦が続いている．前述の ように，短距離走は人にとって最も基本的で単純 な運動であるため，研究材料として頻繁に用いら れてきた。短距離走に関する研究は 1920 年代初 頭より始まり，短距離走技術や本能的な運動とし ての神経・筋機能が調査されてきた（Mero， 1992）。また，生理的機能を知るための負荷方法 としても用いられてきた。研究によって問題が解 決すると新たな課題が生まれ，現在も取り組むべ き課題は多い。本稿では以下のような項目につい てふれたが, 今後の研究課題設定の一助となるこ とができれば幸いである。

I 短距離走の機械的効率

II 短距離走の関節トルク・パワー

III 短距離走の筋活動

IV 筋活動と疾走動作との関係
V 夕イム分析による $100 \mathrm{~m}$ レースパターン

VI 疾走動作と疾走速度との関倸

Iから III に関する研究は短距離走能力を高める ために必要な基礎的な情報を与えてくれる。つま り短距離走がごのような生理機能によってなされ ているのかを知ることは, 疾走技術や体力的な課 題を明らかにするために多くのヒントを与えてく れるからであるＩVからVIの研究成果は，現場 の指導者や選手にとって直接役立つ有益な情報と なる。とくに記録のレベルが高くなった現在は， こういった科学的情報を上手に利用することが成 功を収めるために大切となる，なお，本稿で体力 に関する項目と疾走能力の発達に関する項目につ いては扱わなかったが,これらは大変重要であり， 今後それ自体が題目となった総説が期待される。

\section{I 短距離走の機械的効率}

機械的効率は筋がなした仕事を消費エネルギー で除して求めるが, 古くからその見積もりが試み られてきた．しかし，その計算方法は研究者によ って異なっており（伊藤，1982），厳密には絶対 值の比較は慎重であるべきだろう。Furusawa et al. (1927b) は, 全力疾走時の機械的仕事を推進 力と走行距離の積によって算出し, 消費エネルギ 一を疾走後の酸素負債量から求めている.そして, 得られた 25.0 - $41.0 \%$ という值はカエルやカメの 值と比較してあり得る数值であるとした。Fenn （1930）は，四肢の軍動（内的仕事）と身体重心 の移動 (外的仕事) 加疾走中の機械的仕事量を 算出し，消費エネルギーはSargent（1926）の報 
告などを参考に 13 馬力であると見積り，機械的 効率は $22.7 \%$ あると報告している. Cavagna and Kaneko（1977）は, Fenn (1930) と同じ方 法で機械的仕事を見積もり, Margaria et al. （1963）の平地走行におけるエネルギー消費量は 走速度に関係なく $1 \mathrm{kcal} \cdot \mathrm{kg}^{-1} \cdot \mathrm{km}^{-1}$ とした值 を用いたところ，機械的効率が疾走速度とともに 直線的に高まり，20km/hでは $60 \%$ 以上になると 報告している。そしてこの効率の高まりは， Margaria et al. (1963) と同様に, 伸張性筋収縮 時に筋に蓄えられた弾性エネルギーを，つづく短 縮性筋収縮時に再利用したためであると論じてい る.すなわち，走行中にSSC (Stretch Shortening Cycle：伸張性筋活動が直ちに短縮性筋活動 へ移行する筋活動様式）による筋活動が積極的に おこなわれたことを示唆している。しかし， Kaneko et al.（1983）は短距離選手と長距離選手 について， $3.6 \mathrm{~m} / \mathrm{s}$ から全力走までの機械的効率 をFenn（1930）の方法による機械的仕事と，そ れぞれの被験者についてのエネルギー消費量を酸 素消費量と走行後の血中乳酸值から見積もり, 走 速度の増加とともに低下するという逆の傾向を報 告した。この違いはエネルギー消費量の見積もり の違いによるものであり, 特に無酸素的な運動に
おける消費エネルギーの測定の難しさを示すもの である. Ito et al.（1983）は，機械的効率に影響 を与えると考えられている弾性エネルギーに着日 し，下肢の見かけ上のばね定数をもとにした蓄積 弾性エネルギ一量の見積もりを試み, 走速度の增 加とともにその量が增すことや弾性エネルギーが 蓄積される動作局面を指摘している。また， Ito et al. (1985) は, Fenn（1930）の方法による機 械的仕事をエネルギー消費量の指標としての筋電 四の積分值で除して Electro-Mechanical Efficiency (EME) を算出し, 接地期とスイング期に分 けて比較している。そして, 接地期の EMEはス イング期より高い傾向を観察し，接地期において は弾性エネルギーの再利用によって機械的効率が 高まるのではないかと推察している．機械的仕事 を関節トルクから求める方法が現在推奨されてい るが，その方法を用いて短距離走の機械的効率を 研究したものは見当たらない。なお，図1（伊藤， 1982）は走速度と機械的効率との関係をいくつか の研究結果をもとにしてまとめたものであるが, 短距離走の機械的効率は長距離走に比べて高くな いという示唆を与えるものである。

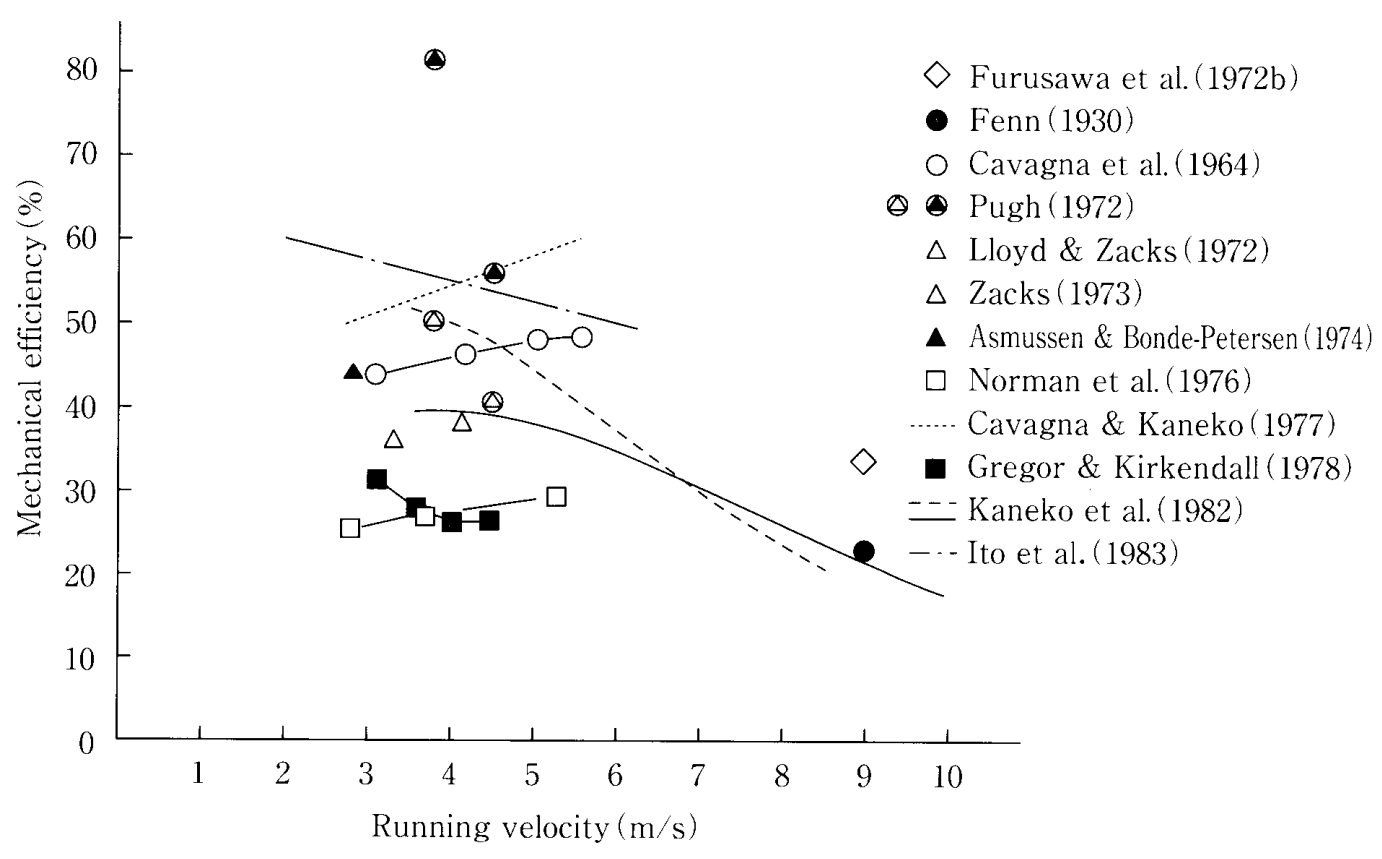

図 1 走速度と機械的効率との関係（例藤，1982） 


\section{II短距離走の関節トルク・パワー}

短距離走における下肢関節トルクやパワーにつ いては, Elftman (1940), Mann (1981), Sprague and Mann (1983), Simonsen et al. (1985), Ae et al. (1985), 阿江ほか (1986), Robertson (1987), Ito et al. (1991)，伊藤章ほ か（1997），馬場ほか（2000）など数多く報告さ れている。 そして報告されている関節トルクやパ ワーの発揮パターンは, どの研究においてもほと んど同じである。その中で，発揮トルク・パワー を量的に扱い，疾走速度との関係から検討してい るのは，伊藤章ほか（1997）のスタートダッシュ から中間疾走までのピークトルクとピークパワー についての報告だけである。そこで, 彼らの結果
をもとに関節トルクとパワーの発揮パターンや量 的な分析結果を概説する.

関節トルタ・パワーの発揮パターンは，スター トから中間疾走まではほとんど変化しない。すな わち，関節トルク（図2左）については，股関節 ではスイング期前半は屈曲トルクを，その後から 接地期中間までは伸展トルクを発揮し，接地期後 半は屈曲卜ルクを発揮した。滕関節ではスイング 期前半は伸展トルク, 後半は屈曲トルクを発揮し, 接地期は伸展トルクを発揮した。足関節では接地 期に伸展卜ルクを発揮した。

関節パワー（図2右）に関しては，股関節では 接地期開始時点から接地期中間時点まではほとん ど正パワーだけを，そして接地期後半は負パワー を発揮した．膝関節ではスイング期全体と接地期 前半にかけてはほとんど負パワーを発揮し，その
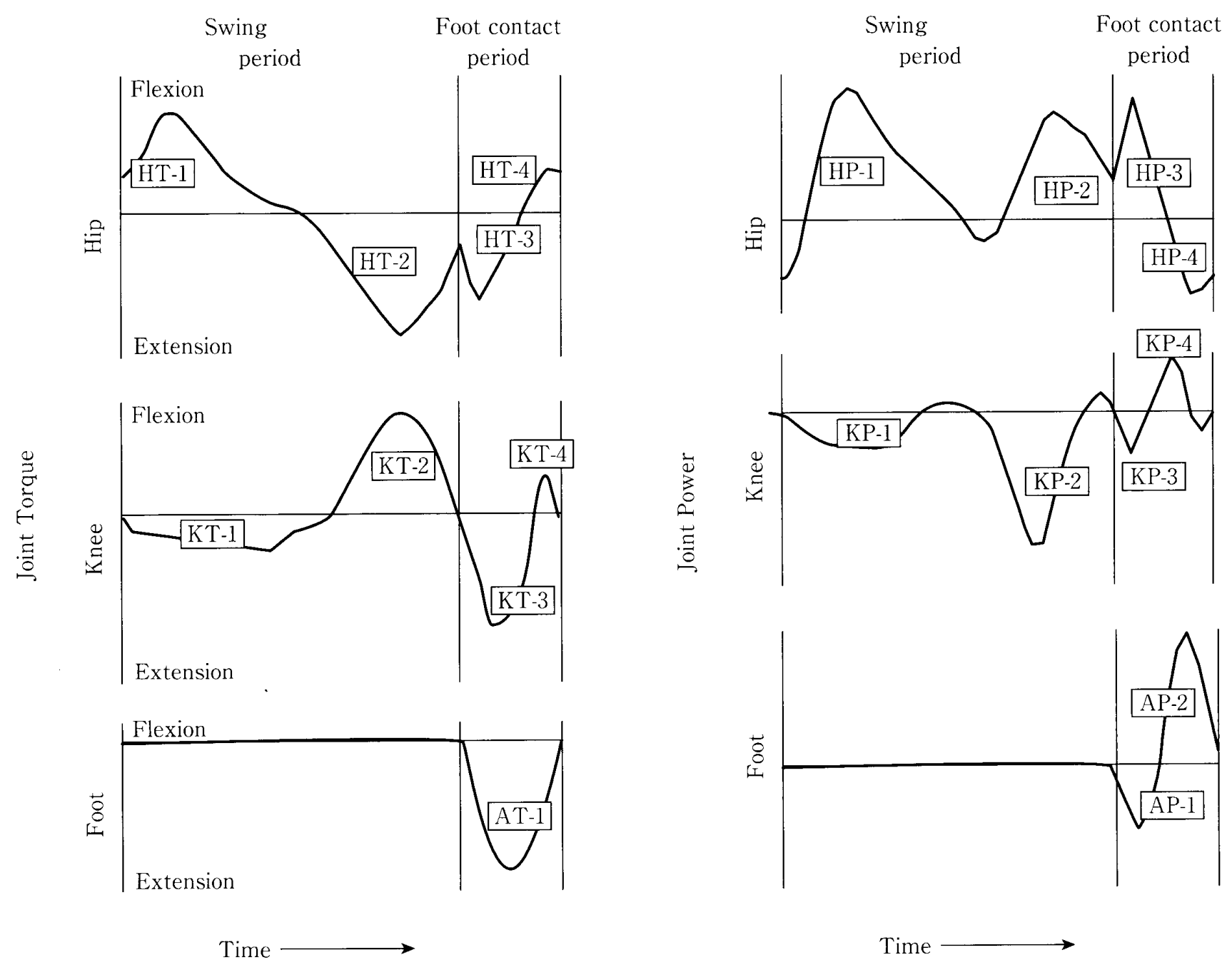

図2 関節トルク・パワーパターン（伊藤ほか, 1997） 
後に正パワーを発揮した。足関節では接地期前半 に負のパワーを，後半に正のパワーを発揮した。 これらの関節パワーは，関節トルクに関節の角速 度を乗じて求めるが，㛜密に言えば正が筋の短縮 性活動を，負が伸張性活動を表すものではない。 Simonsen et al.（1985）や馬場ほか（2000）が報 告しているように，筋・腱複合体の長さ変化を求 めることによって筋活動の状態がわかる.しかし， その方法を用いても筋の長さ変化と腱の長さ変化 が一致するとは限らないので，それによって得ら れた結果は筋活動様式を示すものであり筋収縮様 式とは区別している.

図3に，ピークトルクとピークパワーがスター 卜後の疾走速度（最高疾走速度を1.0で示した相 対值）の増加に対してどのように変化するのかに ついて示した。図中の記号は図2で示した局面に 対応したものである. スタート後の疾走速度とと もに増加したピークトルクは，スイング期の股関 節および膝関節の屈曲と伸展において発揮された
すべてのトルクと，接地期の足関節の伸展トルク だけであった。また，スタートから最高疾走速度 まで高いピークトルクを示したのは，接地期前半 の股関節の伸展トルクであった。スタート後の疾 走速度とともに増加したピークパワーは，スイン グ期前半の股関節の正パワーとスイング期前半と 後半の膝関節の負パワー, および接地期前半と後 半の足関節のそれぞれ負と正のパワーであった。 また，スタートから最高疾走速度まで高いピーク パワーを示したのは接地期前半の股関節の正パワ ーであった。

\section{III 短距離走の筋活動}

短距離走のスタートダッシュにおける筋活動を 筋電図によって調べたものには,松下ほか(1974)， Mero et al. (1987)， Mero and Komi (1990)，伊 藤（1990），伊藤章（1997），馬場ほか（2000）な どの報告があるが，共通する放電パターンは以下
Swing period

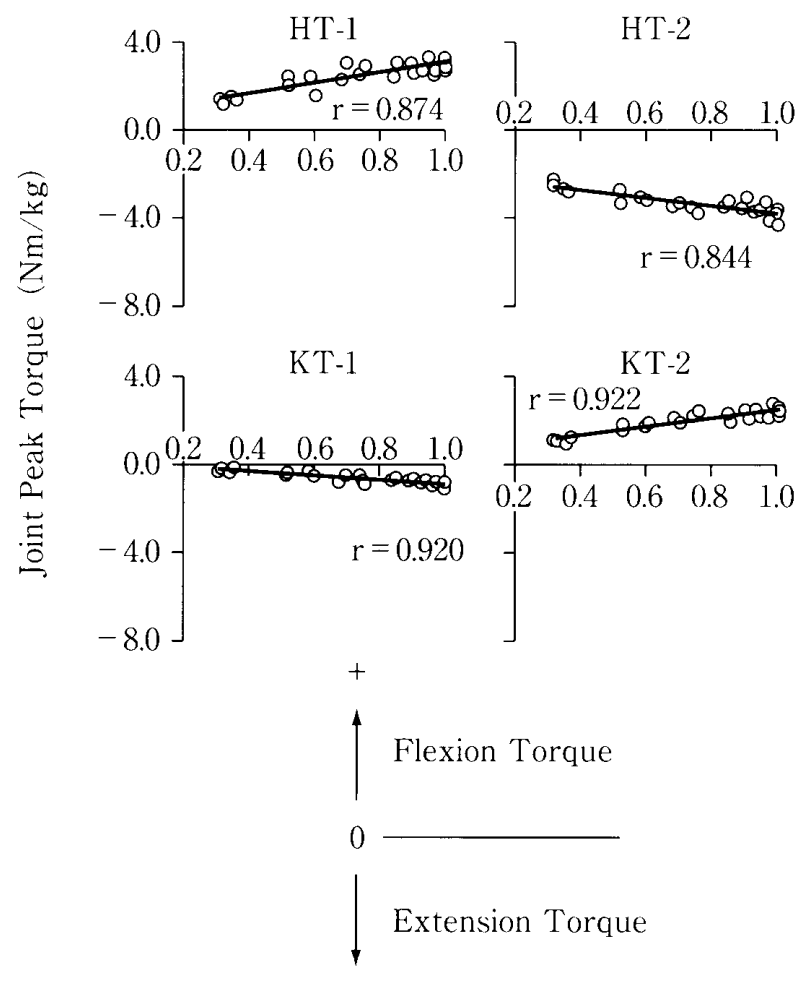

Foot contact period

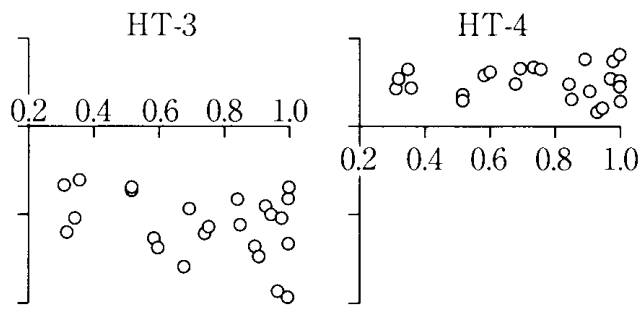

HT-3

HT-4

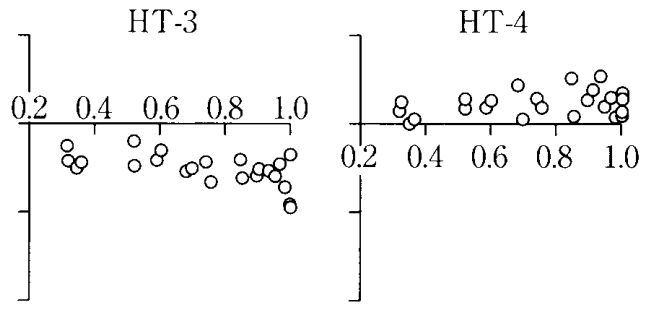

AT-1

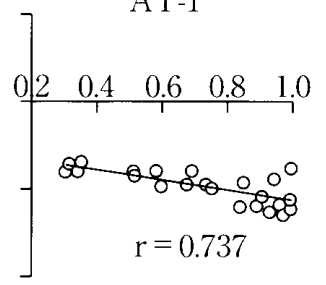

Relative Velocity

図3 スタートからの聅走速度（中間疾走速度に対する相刘值）と関節ピークトルクとの関係（侀藤ほか，1997） 
のとおりである。大殿筋はスイング期後半から接 地期前半にかけて強く放電したが，スタート後 徐々に低下する傾向を示した，外側広筋はス夕ー 卜後のどの歩数においても常にスイング期後半と 接地期前半に放電が見られたが，スイング期前半 と接地期前半に放電が見られた大腿直筋は，接地 期前半の放電についてはスタート後歩数の増加と ともに低下する傾向を示した。大腿二頭筋はスイ ング期中問から接地期終了時点まで強い放電が見 られ，その傾向はスタート後のどの歩数でも同じ であった．腓腹筋はスタート後のどの歩数でもス イング期後半から接地期全体にわたり強い放電が 見られた。

中間疾走に関する筋電図は，松下ほか (1974)， 金子・北村（1975），後藤ほか（1983）, Simon- sen et al. (1985), Mann et al. (1986), Mero and Komi (1987)，伊藤 (1990), Nummela et al.（1994），伊藤章ほか (1997)，馬場ほか（2000） など，スタートダッシュに比べ数多く報告されて いる。そのうち, Simonsen et al. (1985) と馬場 ほか（2000）は筋電図とともに筋の起始から停止 までの筋・腱複合体の長さ変化を関節角度変化か ら算出しているが，馬場ほか（2000）は5名の短 距離選手の平均值で筋電図と筋・腱複合体の長さ 変化を報告しており，個人について報告している Simonsen et al.（1985）より一般性が高い。そこ で，ここでは馬場ほか（2000）の結果（図4）を もとにその特徴を概説する。大殿筋はスイング期 後半から接地期前半にかけて短縮性筋活動を行っ た。大腿二頭筋はスイング期中間時点から伸張性
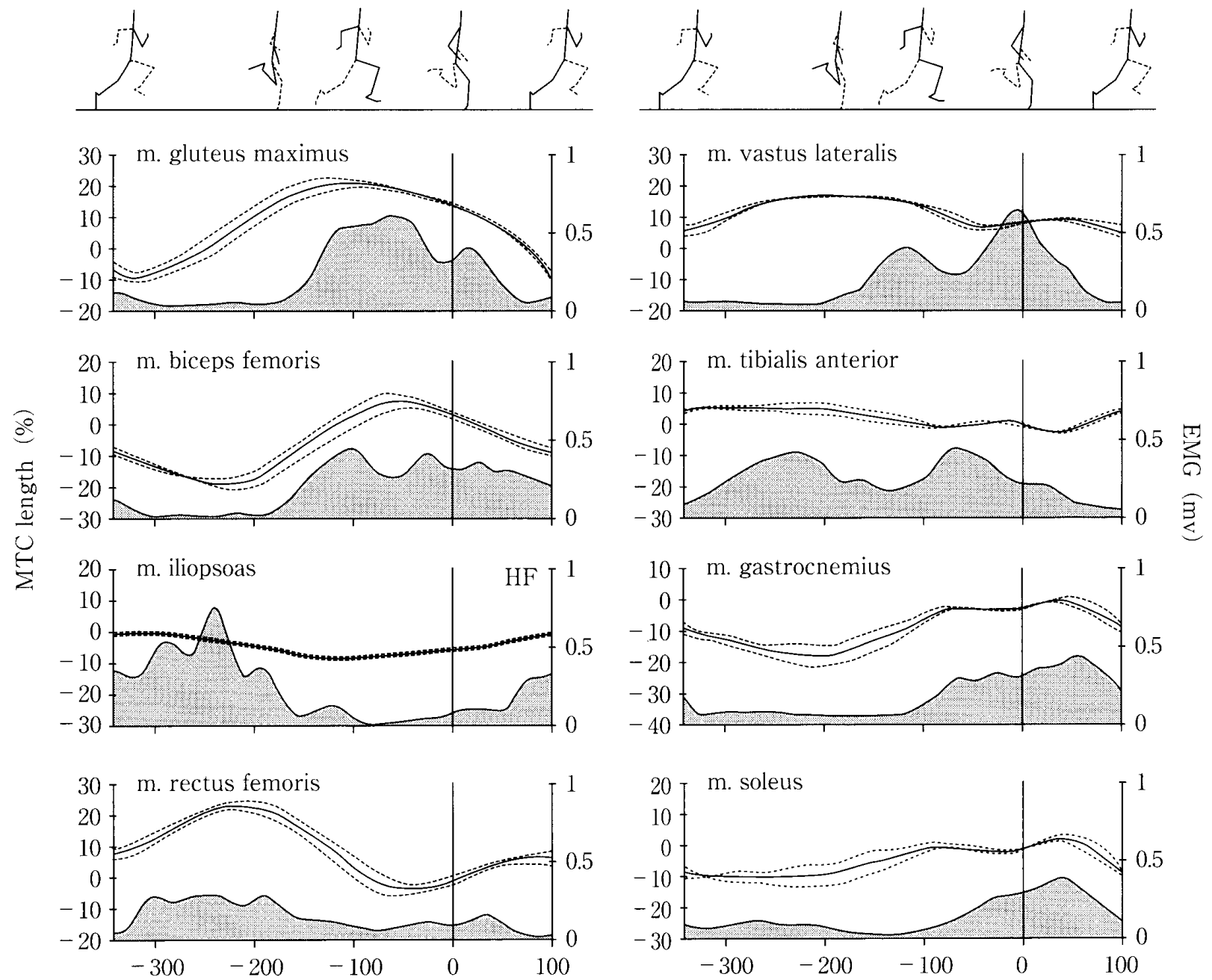

Time (ms)

図4 疾走中の筋・腱複合体の長さ変化と EMG 活動（馬場ほか, 2000） 
筋活動を開始し，スイング期後半の中間時点から 短縮性筋活動に切り替わり, 接地期終了時点まで その活動を持続した，腸腰筋は離地前から伸張性 筋活動を開始し, 離地直後から短縮性筋活動に切 り替わり，スイング期中間時点までその活動を持 続した。 大腿直筋は離地前から伸張性筋活動を開 始し，スイング期前半の中間時点で伸㲀性筋活動 に切り替わり，スイング期中間時点まで持続した。 外側広筋はスイング期中間時点から短縮性筋活動 を開始し，接地直後に伸張性筋活動に切り替わり， その筋活動は接地期中間時点まで持続した。前脛 骨筋はスイング期前半は短縮性筋活動を, 後半は 伸張性筋活動を行った，腓腹筋とヒラメ筋は接地 直前からほほ等尺性の筋活動を開始し，その後接 地開始時点加伸張性筋活動に移行し，接地中間 時点から短縮性筋活動に切り替わった。

\section{IV 筋活動と疾走動作との関係}

疾走動作がどのような筋活動によって始動・調 整されているのかは，筋活動様式と筋電図，関節 トルクなどを同時に測定しなければ明らかにでき ない。馬場ほか（2000）はそれに関して詳細に報 告しており，特に興味深い点について概説する (図 4 参照)。大腿二頭筋はSSC の筋活動によって スイング期後半から接地期にかけて強い股関節伸 展トルクを発揮していた。大腿二頭筋は二関節筋 であるため，この活動は副次的に膝関節の屈曲卜 ルクを発揮する。したがって，そのままにしてお くと，スイング期後半に膝関節は屈曲してしまう ことになる。この局面ではそのとおり膝関節の屈 曲トルクが発揮されているが，外側広筋の活動が 同時に観察されている。この筋活動は外部に関節 トルクとしては現れないが, 前述の大腿二頭筋に よって副次的に発揮されてしまう膝関節の屈曲卜 ルクに対抗するもので，膝関節が屈曲しすぎずに 接地できるように調整するために働いた。接地期 には膝関節の伸展トルクが発揮されるが，外側広 筋は積極的に働き，共同筋である大腿直筋の活動 は抑制的であった。この大腿直筋は二関節筋であ り，その筋活動は股関節の屈曲トルクを発揮する
ことになる，つまり，接地中に大腿直筋が活動す るとキック動作である股関節の伸展を妨げること になるため，抑制されたのである。

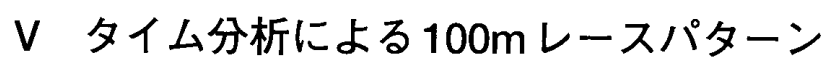

100m 走では, 走者はスタートからゴールまで ほぼ全力で走り抜けるが, 疾走速度はスタート後 すぐに最高速度には達しない。このようなス夕一 卜後の加速の状況をもとに，筋機能や $100 \mathrm{~m}$ レー スのペースについて研究されている．Furusawa et al.（1927a）は筋出力について調査するために, スタート後の疾走速度変化を次のような方法で測 定している。コイルを巻いた支柱を走路に平行に 立て, 走者は胸に磁石を付けて走り, 磁石がコイ ルに近づくと生じる電流を検出して支柱を通過す る時間を求めている。彼らは走者が加速のために 発揮する筋出力はスタートから最高速度に達する まで一定であるとし，その筋出力と粘性抵抗力と の差が外部に現れた推進力であると考え，運動方 程式を立て推進力係数や粘性抵抗による速度の立 ち上がりの遅れをあらわす係数を算出している。 Henry and Trafton（1951）は走路に突き出た竹 の棒を走者が体ではねることで電流回路を開閉さ せることにより通過時間を測定し，猪飼（1965） は光電管を使い Furusawa et al.（1927a）と同様 の測定を行っている.

$100 \mathrm{~m}$ 走のパフォーマンスに結びつけて疾走速 度を分析したGundlach（1963）は，走者の靴の スパイクが地面に接すると電流が流れるように し，スタートから $100 \mathrm{~m}$ までの 1 歩每の速度，歩 幅，歩数の变化を測定した。それによると，疾走 速度はスタート後 $30 \mathrm{~m}-40 \mathrm{~m}$ で最高速度に達し， その後ゴールに近づくにしたがいやや低下するこ とを見出している。また，疾走速度の低下に伴い 歩数も減少することや，記録の良いグループのほ うが歩幅が長く歩数も多いことを報告している. 猪飼（1965）は，小学生（男子160名，女子 151 名）については $50 \mathrm{~m}$ 走, 中学生から大学生（男 子 200 名，女子 167 名）については $100 \mathrm{~m}$ 走の疾 走速度曲線を光電管を用いて测定している。 それ 
によると, 小学生の $50 \mathrm{~m}$ 走では年齢の増加とと もに速度の立ち上がりには变化がないが最高速度 が増加すること，それ以上の年齢の $100 \mathrm{~m}$ 走では Gundlach（1963）と同様に30m-40m で最高速 度に達し，50mから速度の低下が見られること を報告している。猪飼（1965）は日本のオリンピ ック候補選手（東京オリンピック）を含む陸上競 技選手についても测定しており，ス夕ート後 $60 \mathrm{~m}-70 \mathrm{~m}$ 付近から速度の低下が開始する点の 改善を指摘している。これらの研究が日本の短距 離走に関する実践的な科学的取り組みの始まりで あろう。

映画やビデオ分析を用い，世界規模の大会にお ける $100 \mathrm{~m} レ ー ス の$ 疾走速度变化が測定されてい る. International Athletic Foundationによる第 2 回世界陸上競技選手権大会（ローマ，1987）の科 学報告書（1988）によると，男・女選手ともに $30 \mathrm{~m}$ までの加速時間がパフォーマンスに大いに 関係し，優勝者は女子が 4.15 秒，男子が 3.80 秒で あった。最高速度は $30 \mathrm{~m}-60 \mathrm{~m}$ において出現し たが，中にはそれより後で最高速度が出現する選
手もいた。決勝進出者の最高疾走速度は男子が $11.00 \mathrm{~m} / \mathrm{s}$ 以上，女子が $10.50 \mathrm{~m} / \mathrm{s}$ 以上であり，優 勝者は男子が $11.76 \mathrm{~m} / \mathrm{s}$ ，女子が $10.75 \mathrm{~m} / \mathrm{s}$ であっ た。また，男子について $30 \mathrm{~m}-50 \mathrm{~m}$ のタイムと $80 \mathrm{~m}$ - 100m までの夕イムを比較すると，1名を 除き決勝進出者は後半の夕イムのほうが短かかっ た.この傾向は決勝進出者以外ではほとんど観察 されなかった. International Athletic Foundationによる科学報告書（1990）は第14回ソウル オリンピック（1988）についても出版されている. 東京で開催された第 3 回世界陸上競技大会では日 本の研究者たち（阿江ほか，1994）が独自に測定 し，選手個人によって疾走速度曲線のパターンが 異なることを明らかにしている。また，彼らは $100 \mathrm{~m}$ をいくつかの区間に分け，区間夕イムから $100 \mathrm{~m}$ の記録を推定することができる回帰式を明 らかにした（表1）。この回帰式を使えば，短距 離選手の練習の目標を明確に設定することができ るので，指導現場において役立つと思われる。

表1目標記録による標準区間夕イムの推定（阿江ほか，1994）

\begin{tabular}{|c|c|c|c|c|c|c|c|c|}
\hline & $9 " 80$ & $9 " 90$ & $10 " 00$ & $10 " 10$ & $10 " 20$ & $10 " 30$ & $10 " 40$ & $10 " 50$ \\
\hline $0-30 \mathrm{~m}$ & 3.80 & 3.83 & 3.86 & 3.88 & 3.91 & 3.93 & 3.96 & 3.98 \\
\hline $0-60 \mathrm{~m}$ & 6.39 & 6.44 & 6.49 & 6.54 & 6.59 & 6.64 & 6.69 & 6.74 \\
\hline $0-80 \mathrm{~m}$ & 8.07 & 8.14 & 8.22 & 8.29 & 8.36 & 8.44 & 8.51 & 8.58 \\
\hline $30-60 \mathrm{~m}$ & 2.58 & 2.61 & 2.63 & 2.66 & 2.68 & 2.71 & 2.73 & 2.76 \\
\hline $60-80 \mathrm{~m}$ & 1.68 & 1.71 & 1.73 & 1.75 & 1.77 & 1.80 & 1.82 & 1.84 \\
\hline $80-100 \mathrm{~m}$ & 1.73 & 1.76 & 1.78 & 1.81 & 1.84 & 1.86 & 1.89 & 1.92 \\
\hline $60-100 \mathrm{~m}$ & 3.41 & 3.46 & 3.51 & 3.56 & 3.61 & 3.66 & 3.71 & 3.76 \\
\hline
\end{tabular}

\begin{tabular}{|c|c|c|c|c|}
\hline & $10 " 60$ & $10 " 70$ & $10 " 80$ & Estimation error \\
\hline $0-30 \mathrm{~m}$ & 4.01 & 4.03 & 4.06 & \pm 0.04 \\
\hline $0-60 \mathrm{~m}$ & 6.79 & 6.84 & 6.89 & \pm 0.04 \\
\hline $0-80 \mathrm{~m}$ & 8.66 & 8.73 & 8.80 & \pm 0.02 \\
\hline $30-60 \mathrm{~m}$ & 2.79 & 2.81 & 2.84 & \pm 0.02 \\
\hline $60-80 \mathrm{~m}$ & 1.86 & 1.89 & 1.91 & \pm 0.02 \\
\hline $80-100 \mathrm{~m}$ & 1.94 & 1.97 & 2.00 & \pm 0.02 \\
\hline $60--100 \mathrm{~m}$ & 3.81 & 3.86 & 3.91 & \pm 0.04 \\
\hline
\end{tabular}

$$
\begin{array}{rr}
0-30 \mathrm{~m} & \mathrm{Y}=0.251 \mathrm{x}+1.345 \\
0-60 \mathrm{~m} & \mathrm{Y}=0.508 \mathrm{x}+1.408 \\
0-80 \mathrm{~m} & \mathrm{Y}=0.735 \mathrm{x}+0.866 \\
30-60 \mathrm{~m} & \mathrm{Y}=0.257 \mathrm{x}+0.062 \\
60-80 \mathrm{~m} & \mathrm{Y}=0.227 \mathrm{x}-0.542 \\
80-100 \mathrm{~m} & \mathrm{Y}=0.265 \mathrm{x}-0.866 \\
60-100 \mathrm{~m} & \mathrm{Y}=0.492 \mathrm{x}-1.408
\end{array}
$$




\section{VI 疾走動作と疾走速度との関係}

スタートダッシュの動作に関するものは， Volkov and Lapin (1979), Mero et al. (1983), 伊藤ほか (1994)，斉藤ほか（1997）などがある が，実際の競技会に出場中の選手たちのクラウチ ングスタートの姿勢やスタート後の動作を報告し ているのは伊藤ほか（1994）と斉藤ほか（1997） である。斉藤ほか（1997）の報告によると，スイ ング期の動作であるもも上げの高さはスタート後 4歩目まで増加しその後一定の值となり，引き付 け角度はスタート後中間疾走まで減少する傾向を 示し，振り出し角度は逆に増加する。接地期のキ ック脚の最大伸展速度については，股関節の最大 伸展速度はスタート 1 歩目から中間疾走（最高疾 走速度）まで増加し，膝関節の最大伸展速度は逆 に低下したが，足関節はスタート直後より中間疾 走まで変化しなかった。

中間疾走に関しては，Fenn（1930），村瀬ほか (1972)，斉藤ほか (1972)，Mann and Hagy (1980)，斉藤 - 伊藤 (1985), Mann and Herman (1985), Mann et al. (1986)，宮下ほか (1986)， 伊藤ほか（1986），佐川ほか（1997），伊藤道郎ほ か（1997），伊藤ほか（1998），伊藤（2000）, Paradisis（2001）など，数多く報告されている. そして，これらに発育発達に関するものを含める と膨大な数になる。これらの報告のほとんどが， 優秀選手だけを分析したり，速い者とそうでない 者を比較することによって優秀選手の特徵を明ら かにしょうとしたものである.最近の傾向として，

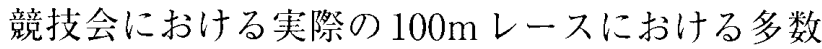
の選手たちの動作を分析することによって，疾走 動作と疾走速度との相関関係をもとに高い疾走速 度を持つ優秀選手の疾走動作の特徴を明らかにし ようとしている．伊藤ほか（1998）は大学短距離 選手から世界の一流選手までの男女71名を対象 に，主に競技大会における100m レース中の中間 疾走動作を分析し，疾走速度との相関関係をもと に高い疾走速度を得るための合理的な疾走動作を 明らかにした。
それによると，スイング脚の動作では，もも上 げの高さ (大腿と鉛直線のなす角度の最大值)や， もも上げ動作後の脚の前方への振出し角度（くる ぶしと大転子を結んだ線と鉛直線のなす角度の最 大值）の大きさは疾走速度に関係なくほほ一定の 大きさであった（四5)。そして，もも上げと同 時に行われる引き付计動作の角度（膝関節の最小 角度）は疾走速度が高い選手ほど大きい傾向を示 した。これらの結果は，一般的に衍われている指 導である「ももを高く上げる」「膝関節を屈曲さ せてももを上げる」「脚を前へ大きく振り出す」 などとは異なるものであった。

キック脚の動作では，接地中の足関節の最大伸 展速度と疾走速度との以下のような関係を明らか にしている（図6）。股関節の最大伸展速度は疾 走速度に関係なくほぼ一定の值を示し，膝関節と 足関節の最大伸展速度は疾走速度が高い選手ほど 低い值を示した。そして，これらの結果から，図 7 を用いて合理的なキック動作について解説して
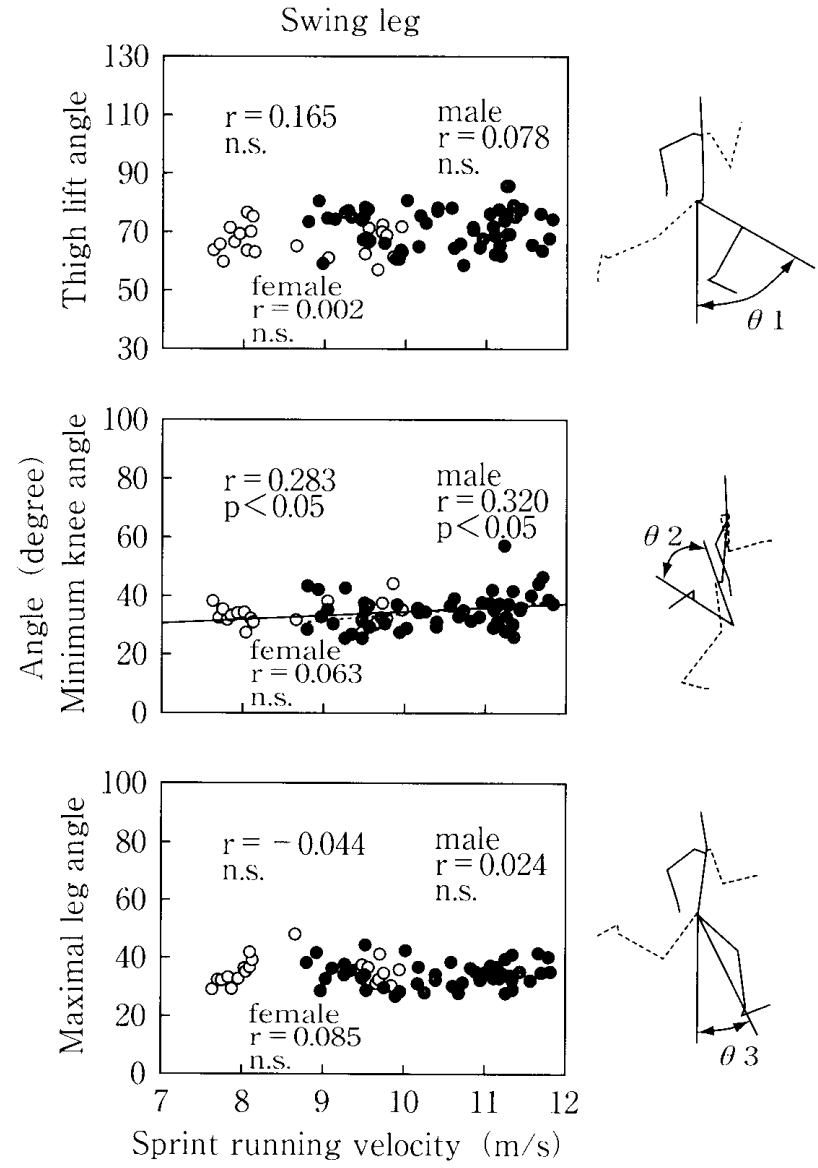

図 5 岑走速度とスイング動作との関係（侀藤ほか，1998） 


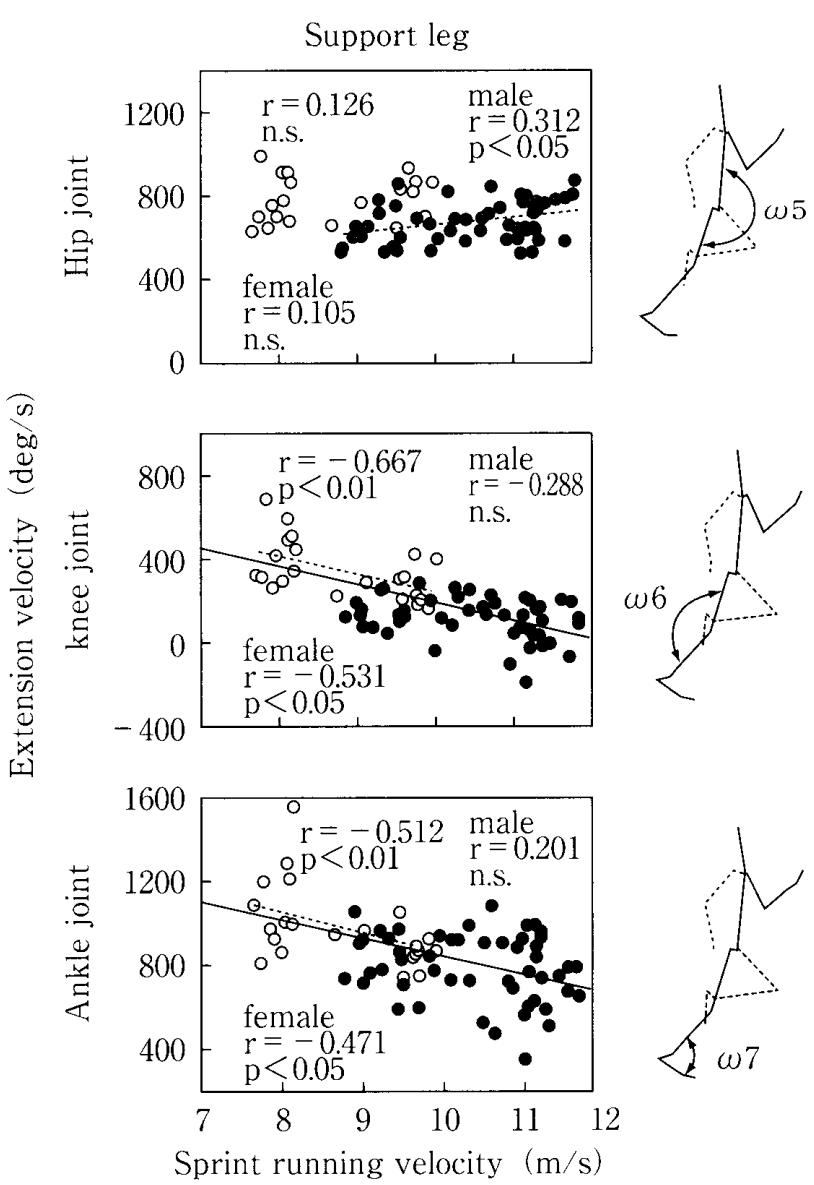

図6 疢走速度とキック動作との関係（伊萠漛ほか, 1998）

いる，図7（A）のように，疾走速度の高い選手 はキックの後半に膝関節を伸展しないため，股関 節の伸展速度が脚全体のスイング速度に変換され 高い疾走速度が得られる。逆に，図7（B）のよ うに，疾走速度の低い選手はキック後半に膝関節 を伸展するため，股関節の伸展速度が膝関節の伸 展動作として吸収されてしまい，脚全体のスイン グ速度に変換されない。さらに，伊藤（2000）は， 足関節の伸展動作が身体重心の上下動を生む原因 となることを示し，疾走速度の高い選手ほど足関 節の最大伸展速度が低い理由を明らかにした。

\section{VII おわりに}

短距離走のパフォーマンスは，筋出力とそれを 走速度へ有効に転換する技術によって決まる。ま ず，短距離走における筋出力に関しては以下のよ うにまとめることができる．機械的効率は筋の伸 張短縮弾性エネルギーの貢献度を示すと考えられ
(B)

(A)

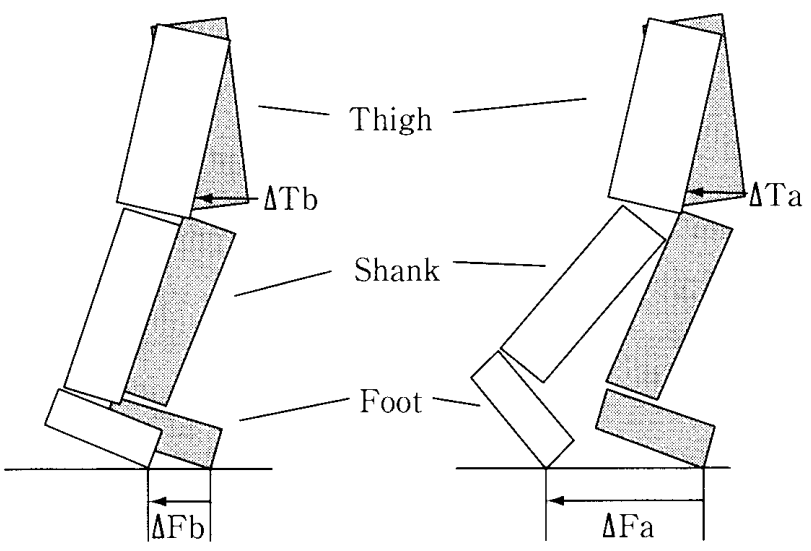

図7 キック動作のモデル（伊藤ほか，1998）

ているが，短距離走のパフォーマンスに筋の弾性 エネルギーがどれほど関与しているのかについて は、これまでの研究では解明されたとはいえない。 しかし，短距離走は長距離走に比べ弾性エネルギ 一がパフォーマンスに貢献する可能性は少ないと 考えたほうが合理的である。なぜなら，多くの研 究結果を総合すると，手法はやや異なってはいる が短距離走のほうが長距離走よりも機械的効率が 低い傾向にあり，短距離走の機械的効率の值が摘 出筋の単純な筋の短縮時の効率に近いからであ る。このことは，短距離走においてより高い疾走 速度を得るには，SSCの筋活動より単純な筋の短 縮力が重要であること示唆している.

上述のように，短距離走ではパワーの発揮が跳 躍時のように弾性エネルギーに頼ることができな いとなれば，なおさら短縮力の強化が必要となる が，それは高い速度で移動する地面に対して短時 間に（疾走速度が高いと接地時間は自ずと短くな ってしまう) 大きな力を発揮できる短縮力である. さらに，筋力・筋パワートレーニングの処方にあ たって，疾走動作と筋力発揮のタイミングを十分 に考慮する必要がある。動作とそれに関与する筋 群と筋活動様式を理解しないで筋力・筋パワート レーニングを処方することはできないからであ る。

短距離走のパフォーマンスは技術的な要因によ っても大きな影響を受ける。合理的な技術を身に 付けるには，まず選手や指導者が合理的な疾走動 
作を客観的に理解しなければならない。これまで の疾走動作に関する研究結果では，もも上げの高 さや引きつけ動作の角度など，キック後の脚を前 へ運ぶ動作は疾走速度に関係しないことが報告さ れている。また，キック動作においては股関節の 伸展速度を脚全体のスイング速度に効果的に変換 するにはキックの後半に膝関節を伸展しないこと が重要であり，足関節の伸展動作（スナップ動作） は身体重心の上下動を少なくするために足関節の 伸張動作（スナップ動作）を少なくすることも重 要であることなど，これまで一般に行われてきた 指導内容と異なった結果も報告されている。つま り，これまでの科学研究の成果がコーチング現場 における指導内容の修正の必要性を指摘し，修正 の方向をも示唆することができたといえよう。

以上，短距離走のこれまでの研究成果を概観し てきたが, 今後の研究課題として, 以下の点を上 げることができよう。1）追跡研究：すでに得ら れた知見を利用して体力トレーニングや技術トレ ーニングを行い，それによってパフォーマンスが どのように変化するのかを調べる。あるいはパフ オーマンスが向上した（低下した）選手の動作や 体力の推移を調へ，研究結果と実践の状況を比較 検討する．2）疾走速度との相関関係：これまで 数多くの研究がなされているが, 疾走速度との関 係を明らかにした研究は少ない。確かにエネルギ 一が必要な作業となるが，パフォーマンスの異な る多くの選手の測定值（例；EMG，地面反力， 関節トルク，動作，体力）と疾走速度との関係を 明確に示すことが求められるだろう。3）競技会 での測定：最高のパフォーマンスは実験条件下で はなく，競技会において得られる。これまで競技 会においては疾走速度変化や疾走動作などが測定 されているが，測定機器の進歩や競技会の主催者 などの協力が得られればさらに多くの知見を得る ことができる．4）生化学的な研究：長距離走に 比べて，エネルギー産生などに関連した研究が著 しく少なく，今後この分野を専門にしている研究 者の活動が期待される．5）研究成果の現場への 還元：指導現場に役立つ普遍性をもった研究成果 を示すことがこれまでの短距離走の研究者の仕事
であったが，今後はそれをどのように現場で活か すことができるのかについて，アイデアを提供す る必要があろう。さらに詳しく短距離走を研究す るだけでなく，短距離走のパフォーマンス向上に 役立つ研究成果を収集し現場に還元することも重 要な課題である。

\section{文献}

Ae, M., Miyashita, K., Shibukawa. K., Yokoi, T., and Hashihara, Y. (1985) Body segment contributions during the support phase while running at different velocities. In: Winter, D.A., Norman, R.W., Wells, R.P., Hayes, K.C and Petla, A.E (Eds.) Biomechanics IX-B. Human Kinetics: Champaign, pp. 343 349 .

阿汇通良・宮下 憲 ·横井孝志 · 大木昭一郎 - 渋川 㑆二（1986）機械的パワーからみた疾走における 下肢筋群の機能および貢献度. 筑波大学体育科学 系紀要 9：229-239.

阿江通良 - 鈴木美紗緒 - 宮西智久 - 岡田英孝 - 平野 敬靖（1994）世界一流スプリンターの100m レース パターンの分析。日本陸上競技連盟強化本部バイ オメカニクス研究班編 世界一流陸上競技者の技 術. ベースボール・マガジン社：東京, pp. 14-28.

Asmussen, E. and Bonde-Petersen, F. (1974) Apparent efficiency and storage of elastic energy in human muscle during exercise. Acta. Physiol. Scand. 92: 537-545.

馬場崇豪・和田幸洋 - 伊藤 章 (2000) 短距離走の 筋活動様式. 体育学研究 45：186-200.

Cavagna, G.A., Saibene, F.P.. and Margaria, R. (1964) Mechanical work in running. J. Appl. Physiol. 19: 249-256.

Cavagna, G.A. and Kaneko, M. (1977) Mechanical work and efficiency in level walking and running. J. Physiol. 268: 467-481.

Elftman, H. (1940) The work done by muscles in running. Am. J. Physiol. 129: 672-684.

Fenn, W.O. (1930) Frictional and kinetic factors in the work of sprint running. Am. J. Physiol. 92: 583611.

Furusawa, K., Hill, A.V., and Parkinson, J.L. (1927a) The dynamics of "Sprint running". Proc. Roy. Soc. B, 102: $29-42$. 
Furusawa, K., Hill, A.V., and Parkinson, J.L. (1927b) The energy used in "Sprint running". Proc. Roy. Soc. B, 102: 43-50.

後藤幸弘・松下健二・本間聖康 - 过野 昭 (1983) 筋電四による走の分析一歩幅・歩数の变化を中心 として一. バイオメカニクス学会編 身体運動の 科学IVスポーツのバイオメカニクス. 杏林書院： 東京, pp. 15-33.

Gregor, R.J. and Kirkendall, D. (1978) Performance efficiency of world class female marathon runners. In: Asmussen, E. and Jorgensen, K. (Eds.) Biomechanics V-B. University Park Press: Baltimore, pp. 40-45.

Gundlach. H. (1963) Laufgeschwindigkeit und Schrittgestaltung im 100-m-lauf. Theorie und Praxis der Körperkultur, H3: 254-262, H4: 346-359, H5: 418-425.

Henry. F.M. and Trafton. I.R. (1951) The velocity curve of sprint running. Res. Quart. 22: 409-422.

猪飼道夫（1965）陸上競技. 東京オリンピックスポ 一ツ科学研究報告. 広研印刷：東京, pp. 37-110. International Athletic Foundation (Ed) (1988) Scientific report on the II world championship in athletics Rome 1987. printed by Marshallarts: England, pp. 135.

International Athletic Foundation (Ed) (1990) Scientific research project at the games of the XXXIV Olympiad-Seoul 1988. printed by Arti Grafiche Danesi: Italy.

伊藤 章（1982）走運動の効率. J. J. Sports Sci. 1： 285-290.

Ito, A., Komi, P.V.. Sjödin, B., Bosco, C., and Karlsson, J. (1983) Mechanical efficiency of positive work in running at different speeds. Med. Sci. Sports Exerc. 15: 299-308.

Ito, A., Fuchimoto. T., and Kaneko, M. (1985) Quantitative analysis of EMG during various speeds of running. In: Winter, D.A., Norman, R.W., Wells, R.P., Hayes. K.C., and Petla, A.E. (Eds.) Biomechanics IX-B. Human Kinetics: Champaign, pp. 301-306. 伊藤 章・古場敬子・金子公有 - 淵本隆文 (1986) 下肢の動作要因と走速度の関係。第 8 回日本バイオ メカニクス学会大会論集. 一ツ橋印刷：東京, pp. $135-139$.

伊藤 章（1990）跳掞よび走に㧍ける下肢筋の筋放
電特性. J. J. Sports Sci. 9：137-142.

Ito, A., Saito, M., Fuchimoto, T., and Kaneko, M. (1991) Progressive changes of joint power in sprint starts. In: Marshall, R.N., Wood, G.A., Elliot, B.C., Ackland, T.R., and McNair, P.J. (Eds) Proceedings of XIII International Congress on Biomechanics. The University of Western Australia: Perth, pp. 7879.

伊藤 章 - 育藤昌久 ・佐川和則 - 加藤謙一 一森田正 利・小木曽一之（1994）世界一流スプリンターの 技術分析. 日本陸上競技連盟強化本部バイオメカ ニクス研究班編 世界一流陸上競技者の技術。べ ースボール・マガジン社：東京, pp. 31-49.

伊藤 章・斉藤昌久・淵本隆文（1997） ス夕ート夕 ッシュにおける下肢関節のピークトルクとピーク パワー, 拉よび筋放電パターンの変化. 体育学研 究 $42: 71-83$.

伊藤 章 - 市川博啓 - 斉藤昌久 - 佐川和則 - 伊藤道 郎・小林寛道（1998）100m 中間疾走局面に打ける 疾走動作と速度との関係. 体育学研究 43 : 260273.

伊藤 章（2000）短距離走に扔けるスナップの意味. バイオメカニクス研究 $4: 159-163$.

伊藤道郎 · 斉藤昌久 ·佐川和則 - 市川博啓 - 加藤謙 一・伊藤 章 (1997) アジア女子トップスプリン ターの中間疾走フォーム。 日本陸上競技連盟強化 本部バイオメカニクス研究班編 アジア一流陸上 競技者の技術．創文企画：東京, pp. 49-63.

金子公宥・北村潔和（1975）100m 疾走のスピード莪 減要因に関するキネシオロジー的分析，日本体育 協会スポーツ研究報告 5：12-20.

Kaneko, M., Ito A., Fuchimoto, T., and Toyooka, J. (1983) Effects of running speed on the mechanical power and efficiency of sprint and distance runners. J. Physiol. Soc. Japan 45: 711-713.

Lloyd, B.B. and Zacks, R.M. (1972) The mechanical efficiency of treadmill running against a horizontal impeding force. J. Physiol. 223: 355-363.

Mann, R.A. and Hagy, J. (1980) Biomechanics of walking, running, and sprinting. Am. J. Sports Med. 8: 345-350.

Mann, R.V. (1981) Kinetic analysis of sprint running. Med. Sci. Sports Exerc. 13: 325-328.

Mann, R. and Herman. J. (1985) Kinematic analysis of Olympic sprint performance: Mens 200 meters. Int. 
J. Sport Biomech. 1: 151-162.

Mann, R.V., Moran, G.T., and Dougherty, S.E. (1986) Comparative electromyography of the lower extremity in jogging, running, and sprinting. Am. J. Sports Med. 14: 501-510.

Margaria, R., Cherretelli, P., Aghemo, P., and Sassi, G. (1963) Energy cost of running. J. Appl. Physiol. 18: $367-370$.

松下健二 · 後藤幸弘 - 岡本 勉 - 过野 眧 - 熊本水 頼（1974）走の筋電図的研究. 体育学研究 19： $147-156$.

Mero, A., Luhtanen, P., and Komi, P.V. (1983) A biomechanical study of the sprint start. Scand. J. Sci. 5: $20-28$.

Mero, A. and Komi, P.V. (1987) Electromyographic activity in sprinting at speeds ranging from submaximal to supra-maximal. Med. Sci. Sports Exerc. 19: $266-274$.

Mero, A. and Komi, P.V. (1990) Reaction time and electromyographic activity during a sprint start. Eur. J. Appl. Physiol. 61: 73-80.

Mero, A., Komi, P.V., and Gregor, R.J. (1992) Biomechanics of Sprint Running. Sports Medicine 13: $376-392$.

宮下 憲 ·阿汇通良・横井孝志・橋原孝博 · 大木昭 一郎（1986）世界一流スプリンターの疾走フォー 厶の分析. J. J. Sports Sci. 5 ： 892-898.

宫丸凱史編 (2001) 疾走能力の発達。杏林書院：東 京.

Norman, R.W., Sharatt, M.T., Pezzack, J.C., and Noble, E.G. (1976) Re-examination of the mechanical efficiency of horizontal tredmill running. In: Komi (Ed) Biomechanics V-B. University Park Press: Baltimore, pp. 87-93.

Paradisis, G.P. and Cooke, C.B. (2001) Kinematic and postural characteristics of sprint running on sloping surfaces. J. Sports Sci. 19: 149-159.

村瀬 豊・亀井貞次 - 星川 保 - 宮下充正・松井秀 治（1972）陸上競技選手と非鍛錬者とに見られる 走行中の足の動きの速さの違いについて，体育学 研究 $16: 273-279$.

Nummela, A., Heikki, R., and Mero, A. (1994) EMG activities and ground reaction forces during fatigued and nonfatigued sprinting. Med. Sci. Sports Exerc.
26: $605-609$.

Pugh, L.G.C. (1971) The influence of wind resistance in running and walking and mechanical efficiency of work against horizontal or vertical forces. J. Physiol. 213: 255-276.

Robertson. D.G. (1987) Function of the leg muscles during the stance phase of running. In: Jonsson, B. (Ed) Biomechanics X-B. Human Kinetics: Champaign. pp. $1021-1027$

佐川和則 - 斉藤昌久・作藤道郎・加藤謙一・市川博 啓・伊藤 音 (1997) アジア・トップスプリンタ 一の門疾走フォーム。日本陸上競技連盟強化本 部バイオメカニクス研究班編 アジア一流陸上競 技者の技術，創文企画：東京，pp. 33-48.

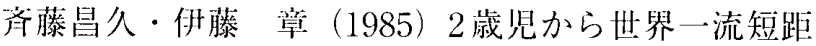
離選手までの中間疾走能少の变化。体育学研究 $40: 104-111$.

斉藤昌久 - 伊藤 章・作川和則 - 伊藤道郎 - 加藤謙 一・甫川博弊（1997）アジア・トップスプリンタ ーのスタートダッシュの動作分析．日本陸上競技 連盟强化本部バイオメカニクス研究班編 アジア 一流樊上競技者の技術。創文企西：東京，pp. 1131.

斉藤 满 - 星川 保 - 宮下充正・松井秀治 (1972) 走速度堌加に対応する下肢関節の動きについて。 体青学研究 $16 ： 265-271$.

Sargent, R.M. (1926) The relation between oxygen requirement and speed in running. Proc. Roy. Soc. B, 100: $10-22$.

Simonsen, E.B., Thomsen, L., and Klausen, K. (1985) Activity of mono-and biarticular leg muscles during sprint running. Eur. J. Appl. Physiol. 54: 524532.

Sprague, P. and Mann, R.V. (1983) The effects of muscular fatigue on the kinetics of sprint running. Res. Q. Exerc. Sport 54: 60-66.

Volkov, N.I. and Lapin, V.I. (1979) Analysis of the velocity curve in sprint running. Med. Sci. Sports Exerc. 11: 332-337.

Zacks, R.M. (1973) The mechanical efficiency of running and bicycling agaist a horizontal impeding force. Int. Z. angew. Physiol. 31: 249-258.

$\left(\begin{array}{l}\text { 平成 } 14 \text { 年 } 9 \text { 月 } 20 \text { 日受付 } \\ \text { 平成 } 15 \text { 年 } 1 \text { 月 } 25 \text { 日受理 }\end{array}\right)$ 